\title{
Serum Thyrotropin during Daily Life and in Response to Thyrotropin Releasing Hormone in Normal Subjects and Juvenile Diabetics
}

\author{
J. Weeke and Aa. Prange Hansen \\ Second University Clinic of Internal Medicine, Kommunehospitalet, Aarhus, Denmark \\ Received: July 15, 1973, and in revised form: October 30,1973
}

Summary. Serum thyrotropin (TSH) and growth hormone $(\mathrm{GH})$ were measured in 24 women and 25 men with juvenile diabetes and in comparable normals. Samples were obtained in the postprandial state at 11 a.m., during a $24 \mathrm{~h}$ period of daily life and after thyrotropin releasing hormone (TRH) stimulation. The diurnal TSH rhythm in the diabetics was similar to that found in normals. The TSH values at the nadir of the diurnal TSH rhythm (11 a. $\mathrm{m}$.) were identical in diabetics and normals; in addition there was no difference in the TSH response to TRH. No sex dependent difference of the basal TSH level or of TSH response to TRH was present. Serum GH was higher in women than in men, and higher in diabetics than in normals. The study indicates that diabetes meliitus is not likely to be a disease accompanied by a generalized hypothalamic dysfunction.

Key words: Serum TSH, serum GH, TRH, juvenile diabetes.
It is well known that serum GH during normal life and in response to different stimuli is increased in juvenile diabetics, and the subject has been recently reviewed [1]. We have proposed the hypothesis that this $G H$ hypersecretion is a causal factor in the development of diabetic angiopathy [2]. It is an intriguing possibility that the observed GH hypersecretion is an indication of a generalized hypothalamic dysfunction. Pfeiffer and his coworkers [3] have recently claimed that TSH during basal conditions and in response to TRH is greatly increased in juvenile diabetics. We have thought it of interest to reinvestigate their finding.

\section{Materials and Methods}

All subjects investigated were young and nonobese. They were euthyroid by clinical examination and none of them had a goitre. The diabetics were all of juvenile type. They were examined in their usual control state. All the diabetics received insulin. No other medication was used by any of the subjects. None used oral contraceptives.

\section{1 a.m. Samples}

Four groups of subjects were selected: 32 normal women, 17 diabetic women, 23 normal men and 20 diabetic men. Their clinical data appear in Table 1. Six of the 37 diabetics had mild to moderate angiopathy. One venous blood sample was drawn in the ambulatory state at 11 a.m. All subjects had had their usual breakfast at the usual time. The diabetics had received their usual insulin dose in the morning. No precaution was taken to avoid the middle of the menstrual cycle in this part of the study. TSH was measured in blood samples collected at 11 a.m., because of the circadian variation in serum TSH $[4,5]$.

Table 1. Clinical data for subjects examined with 11 a.m. samples

\begin{tabular}{|c|c|c|c|c|}
\hline & $\begin{array}{l}\text { Normal women } \\
n=32\end{array}$ & $\begin{array}{l}\text { Diabetic women } \\
\mathrm{n}=17\end{array}$ & $\begin{array}{l}\text { Normal men } \\
n=23\end{array}$ & $\begin{array}{l}\text { Diabetic men } \\
n=20\end{array}$ \\
\hline Age (years) & & & & \\
\hline $\begin{array}{l}\text { Mean } \pm S D \\
\text { Height }(\mathrm{cm})\end{array}$ & $30 \pm 10.1$ & $27 \pm 8.3$ & $29 \pm 9.1$ & $27 \pm 9.1$ \\
\hline $\begin{array}{l}\text { Mean } \pm \text { SD } \\
\text { Weight (kg) }\end{array}$ & $165 \pm 6.2$ & $166 \pm 5.6$ & $181 \pm 6.8$ & $178 \pm 6.5$ \\
\hline $\begin{array}{l}\text { Mean } \pm S D \\
\text { Diabetes duration (years) }\end{array}$ & $56.7 \pm 5.05$ & $60.0 \pm \quad 8.33$ & $73.7 \pm 8.93$ & $71.2 \pm \quad 7.40$ \\
\hline $\begin{array}{l}\text { Mean } \pm \text { SD } \\
\text { Blood glucose } \mathrm{mg} / 100 \mathrm{ml} \text { ) }\end{array}$ & - & $12 \pm 7.6$ & - & $8 \pm 8.1$ \\
\hline $\begin{array}{l}\text { Mean } \pm \text { SD } \\
\text { Serum TSH }(\mu \mathrm{U} / \mathrm{ml})\end{array}$ & $91 \pm 12.8$ & $264 \pm 117.3$ & $88 \pm 13.0$ & $261 \pm 104.2$ \\
\hline $\begin{array}{l}\text { Median and range } \\
\text { Mean } \pm \text { SD } \\
\text { Serum GH }(\mathrm{ng} / \mathrm{ml})\end{array}$ & $\begin{array}{c}0.5(<0.2-2.3) \\
0.7 \pm 0.50\end{array}$ & $\begin{array}{c}0.8(<0.2-2.7) \\
0.9 \pm 0.84\end{array}$ & $\begin{array}{l}0.7(<0.2-2.5) \\
0.8 \pm 0.64\end{array}$ & $\begin{array}{c}0.5(<0.2-3.2) \\
0.7 \pm 0.69\end{array}$ \\
\hline $\begin{array}{l}\text { Median and range } \\
\text { Mean } \pm \mathrm{SD}\end{array}$ & $\begin{array}{l}3.1(1.2-42) \\
\quad 6.6 \pm 8.84\end{array}$ & $\begin{array}{l}6.5(1.3-43) \\
14.4 \pm 13.69\end{array}$ & $\begin{array}{l}2.0(0.7-6.2) \\
\quad 2.3 \pm 1.25\end{array}$ & $\begin{array}{l}3.9(1.6-37) \\
7.4 \pm \quad 8.55\end{array}$ \\
\hline
\end{tabular}




\section{$24 h$ Studies}

Two diabetic women without angiopathy were studied. They received three meals at fixed times and the usual insulin dose during the $24 \mathrm{~h}$. They were sitting, talking and reading in a quiet room; during the night they slept. Blood was drawn from an indwelling venous catheter every half hour.

\section{TRH Stimulation}

Four groups of subjects were investigated: five normal women, five diabetic women, six normal men and five diabetic men. None of the diabetics had angiopathy. All subjects arrived at the hospital in the fasting state between 7 and 9 a.m. An indwelling venous catheter was inserted immediately and blood sampling was started after half an hour's rest. Two basal samples were taken $15 \mathrm{~min}$ and immediately before the injection of TRH. $200 \mu \mathrm{g}$ TRH was injected intravenously as fast as possible and blood samples were drawn 5, 10, $15,20,25,30,45,60$ and $120 \mathrm{~min}$ following the injection. The subjects were supine during the entire procedure. No stimulation was performed in the 14 days between the 11 th and 25 th day after start of menstrual bleeding in an attempt to avoid stimulation around the time of ovulation.

Serum was stored at $-20^{\circ} \mathrm{C}$ until analysis. TSH and $\mathrm{GH}$ were determined radioimmunologically by single antibody, wick chromatographic techniques, previously described $[6,7]$. As TSH standard the MRC standard A Human TSH was used. Serum glucose was determined by a glucose oxidase method. The statistical analyses were performed with Student's $t$ test or Wilcoxon's rank-sum test.

\section{Results}

\section{1 a.m. Samples}

The individual TSH values in the four groups appear in Fig. 1. The ranges and distribution patterns in the four groups are nearly identical. Table 1 shows the medians and means in the four groups. There was no statistically significant difference between the TSH values of women and men or between normals and diabetics. The GH values in the four groups are shown in Table 1. The GH values were higher in normal women than in normal men $(2 \alpha=0.001)$, in diabetic women compared with normal women $(2 \alpha<0.01)$ and in the diabetic men compared with normal men $(2 \alpha<0.01)$. However, a higher GH level in the diabetic women than in the diabetic men could not be shown in this series. The postprandial blood glucose level in the four groups is given in Table 1 . There was no difference between the levels in diabetic women and men. A significant correlation between blood glucose and TSH and between blood glucose and GH could not be shown. Moreover, there was no significant correlation between TSH and GH.
$24 h$ Studies

The circadian variation of TSH in two diabetic women is shown in Fig. 2. TSH levels fluctuate, but it can be seen that the TSH values are lower during the day-time than during the night, a pattern similar to that earlier described in normals $[5,6]$. The GH level in the two diabetic women showed many more peaks during the $24 \mathrm{~h}$ than is usually seen in normals. This pattern is identical to that earlier found in diabetic women [8]. There was no constant time relation between the TSH and GH peaks and the amplitudes of the peaks were not correlated with each other.

\section{TRH Stimulation}

Fig. 3 shows the TSH response to TRH in the 11 normals and 10 diabetics. The mean basal level was slightly lower in the diabetics than in the normals $(1.3 \pm 1.18 \mu \mathrm{U} / \mathrm{ml}$ as against $1.5 \pm 0.85 \mu \mathrm{U} / \mathrm{ml}$ (Mean \pm $\mathrm{SD})$. This difference was not statistically significant. In both diabetics and normals TSH increased rapidly after TRH and reached a maximum value $25-30 \mathrm{~min}$ after injection of TRH. The maximum value was also slightly lower in the diabetics than in the normals $(9.9 \pm 6.86 \mu \mathrm{U} / \mathrm{ml}$ as against $11.0 \pm 5.19 \mu \mathrm{U} / \mathrm{ml}$ $($ Mean $\pm S D)$ ), but again this difference was not statistically significant. Moreover, there was no difference between diabetics and normals in the absolute or percentage TSH increase from basal values. The TSH response to TRH was identical in women and men.

\section{Discussion}

It appears from the present study that the TSH level at 11 a.m., the circadian TSH rhythm and the TSH response to TRH in groups of juvenile diabetics are indistinguishable from values found in comparable normals.

Raptis et $a l$. [3] have recently published, in abstract, their results from a study on TSH in juvenile diabetics. They found, in a group of normal subjects, an average basal TSH level of $11.8 \mu \mathrm{U} / \mathrm{ml}$ and a maximal rise to $26.7 \mu \mathrm{U} / \mathrm{ml}$ during TRH stimulation (200 $\mu \mathrm{g}$ TRH). In a group of juvenile diabetics they found an average basal TSH level of $27.1 \mu \mathrm{U} / \mathrm{ml}$ and a maximum rise during TRH stimulation to $39.3 \mu \mathrm{U} / \mathrm{ml}$. Their results in the normal group differ from our results in two ways. Their basal TSH level is about 10 times higher than the basal level in our study and their peak value during TRH stimulation is only two-fold higher than basal level, whereas the peak value in our study is seven fold higher than the basal level. The discrepancy between our results and theirs is unexplained. It may be due to differences in the TSH assay techniques. The high basal values of Raptis et al. are much higher than those which recently have come to be regarded as representing endogenous TSH content in serum [9]. The basal TSH values were identical in women and men. This 
has not been demonstrated earlier with a sensitive and specific TSH assay.

No precaution was taken in our study to avoid the midcycle period in the experiments when the 11 a.m. samples were drawn. We have since shown that the fasting morning TSH level and the TSH level at 11 a.

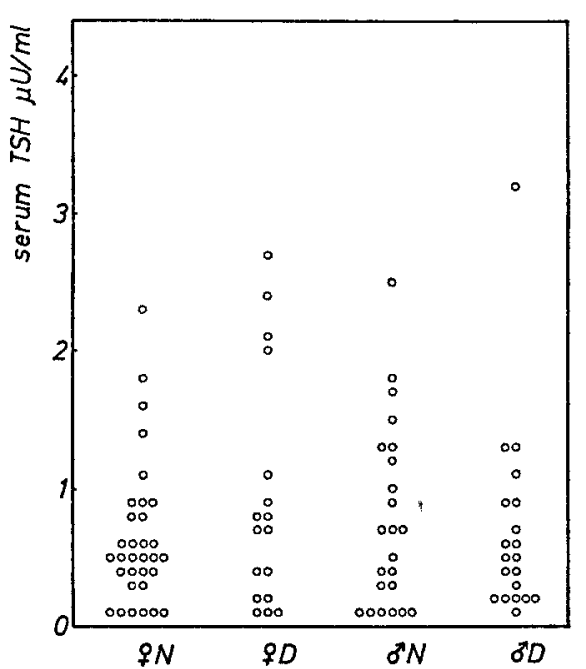

Fig. 1. Individual serum TSH values at 11 a.m. in the normal women, diabetic women, normal men and diabetic men
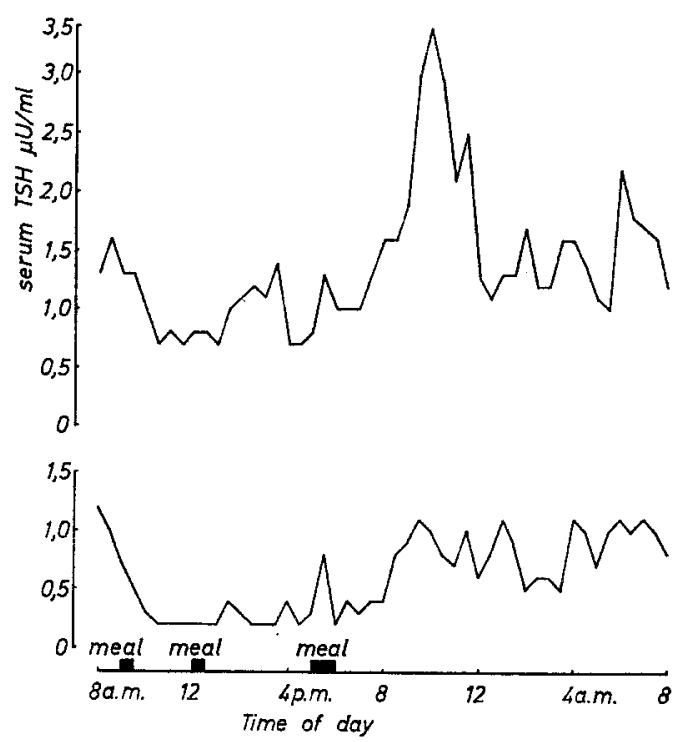

Fig. 2. Serum TSH in 2 diabetic women throughout a $24 \mathrm{~h}$ period

m. do not vary during the menstrual cycle in normally menstruating women (Weeke and Hansen, to be published). The TRH stimulation was not performed in the period around ovulation. So far the influence of ovulation on the TSH response to TRH is unknown.

The TRH stimulation tests were performed before the circadian variation in TSH was discovered. The
TRH stimulation tests were performed between 7 and 9 a.m., at a time where the TSH level decreases from the higher night values to the lower day-time values. This explains why the basal TSH levels in the TRH stimulation tests were higher than the TSH levels at 11 a.m.

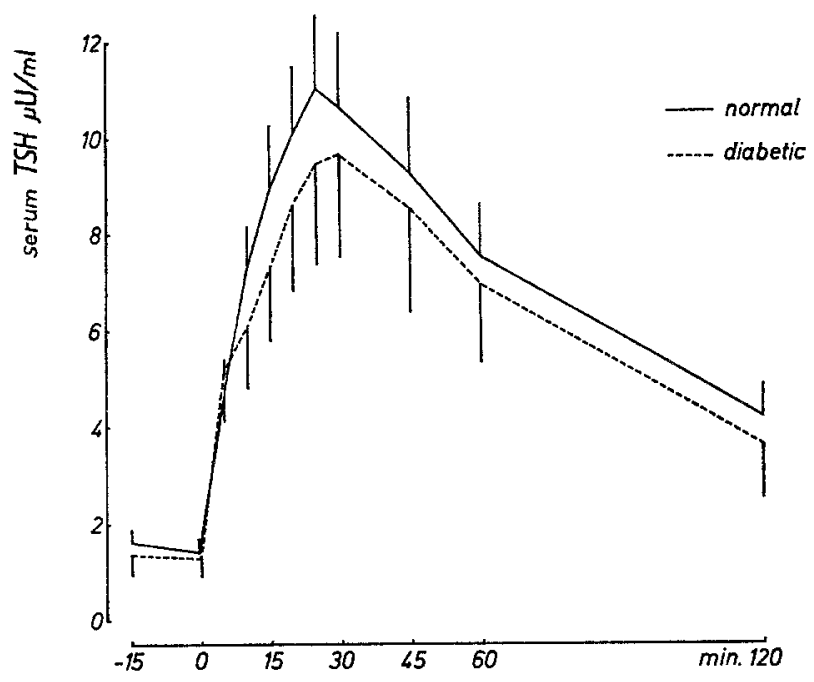

Fig. 3. Average serum TSH response to TRH in 11 normals and 10 diabetics (Mean \pm SEM)

The diabetic patients studied have shown GH hypersecretion with elevated basal values and fluctuating 24 -h values. In spite of this abnormality in GH, serum TSH was found to be quite normal in these patients. This disparity indicates that diabetes mellitus is not likely to be a disease accompanied by generalized hypothalamic dysfunction.

Acknowledgements. The gifts of human TSH and antiTSH serum and of human GH from the Pituitary Agency of the National Institute of Health, Bethesda, Maryland, U.S.A. and of human TSH research standard A from the National Institute of Medical Research, London, are gratefully acknowledged. We are grateful to F. HoffmanLa Roche \& Co. for supplying synthetic TRH. The study was supported by grants from NOVO Research Foundation and from Statens laegevidenskabelige Forskningsråd. We are most grateful to Ketty Jensen, Inga Bisgaard and Birthe Anette Bindslev for conscientious technical assistance.

\section{References}

1. Hansen, Aa.P.: Serum growth hormone patterns in juvenile diabetes. (Thesis). Dan. med. Bull. Suppl. 1, $1-32$ (1972)

2. Lundbaek, K., Christensen, N.J., Jensen, V.A., Johansen, K., Olsen, T.S., Hansen, Aa.P., Ørskov, H., Østerby, R.: Diabetes, diabetic angiopathy, and growth hormone. Lancet 1970 II, $131-133$

3. Raptis, S., Rothenbucher, G., Birk, J., Loss, U., Schleyer, M., Pfeiffer, E. F.: Insulin dependent diabetes mellitus and HGH, TSH in serum following thyrotropin releasing factor (TRF). (Abstract). Acta endocr. (Kbh.) Suppl. 155, 182 (1971) 
4. Patel, Y.C., Alford, F.P., Burger, H.G.: The $24 \mathrm{~h}$ plasma thyrotropin profile. Clin. Sci. 43, $71-77$ (1972)

5. Weeke, J.: Circadian variation of the serum thyrotropin level in normal subjects. Scand. J. clin. Lab. Invest. 31, $337-342(1973)$

6. Weeke, J., Ørskov, H.: Wick-chromatography for the immunoassay of serum thyrotropin. J. Lab. clin. Med. $82,158-165$ (1973)

7. Ørskov, H., Thomsen, H.G., Yde, H. : Wick-chromatography for rapid and reliable immunoassay of insulin, glucagon and growth hormone. Nature 219, 193-195 (1968)

8. Hansen, Aa.P.: Serum growth hormone patterns in female juvenile diaboties. J. clin. Endocr. 36, 638-645 (1973)
9. Adams, D.D., Kennedy, T.H., Utiger, R.D.: Comparison of bioassay and immunoassay measurements of serum thyrotropin (TSH) and study of TSH levels by immunoassay of serum concentrates. J. clin. Endocr. $34,1074-1079(1972)$

J. Weeke, M.D.

Kommunehospitalet

Second Univ. Clinic of Internal

Medicine

DK-8000 Aarhus

Denmark 